\title{
Implied Contract and the Law of Literary Property
}

Benjamin Kaplan*

$\mathrm{T}$ 'HE SUBJECT assigned to me seems very broad. I have, however, been admonished by the Chairman of this Institute, whose relation to the speakers is that of Svengali to Trilby, to confine myself and to give only an explication of text of the recent California cases. In approaching these cases I suffer from the handicap of being an outsider: I am not a California lawyer and I have no intimate knowledge of the workings of the motion picture, radio or television business. On the other hand, there may be some advantage in hearing from the man from Mars - or Cambridge; he will be long on theory and short on practice, but he will come to his task without predispositions.

We all know how cases of this sort arise. A writer or "idea man" claims to have submitted to a producer a play or scenario, or an outline of a story, or a radio or television program or format or plan; and he asserts that the producer later used his work in a motion picture or a program on the air without acknowledgment or payment. The cases will range from the amateur who sends in a sketch without solicitation by the producer, to the professional free lance who at the 'invitation of the producer submits a complete job which is made the subject of some negotiation.

The difficulties in adjudging these cases are well-known and could be anticipated even by one unfamiliar with the legal theories put forward or with the decisions on the books. The similarities claimed to exist between the work submitted and the final production tend to be elusive, just as the circumstances of the submissions often lend themselves to varying interpretations. Courts are torn as much by the desire to prevent a shabby producer from bilking an honest writer of his due, as by the desire to prevent a slippery writer from impressing a polite form of extortion on an innocent producer. In many cases what is copied, if it is copied at all, is a tawdry thing which is apt to strike a court (particularly after the event) as being of little or no artistic merit; yet the court is aware that, in the frenzied competition for a piece of the public's mind, a "gimmick," a seemingly trivial variation on some old piece of hocus-pocus, may have or may be thought by producers to have large commercial value.

It is not surprising, therefore, that the California Supreme Court was much disturbed by the Golding and Stanley cases in 1949-50, as compari-

* Professor of Law, Harvard University. 
son of the original opinions with the opinions on rehearing will show ${ }^{1}$ nor is it surprising that the court seems to have altered its views in the later cases of Weitzenkorn and Kurlan in $1953 .^{2}$ It is a strange fact of history that the Supreme Court seems not to have dealt with these problems before, although there had been a few prior cases in lower California courts.

I.

Let me attempt a brief and generalized summary of the development of doctrine in the Supreme Court.

Two theories of recovery have been pressed on the court: (1) wrongful appropriation or infringement of copyright (i.e., that copyright in a writer's unpublished work which is preserved by section 2 of the Federal copyright statute $^{3}$ for protection by the States); (2) breach of contract--express, implied-in-fact, or implied-in-law-grounded in one way or another on the supposed relationship or dealings between the parties.

On rehearing of the Golding case, in which a play about a neurotic sea captain was allegedly infringed by a motion picture, the majority seems to have adopted an unconventional and very generous view of the scope of copyright, aided possibly by the provisions of the California Civil Code in force when the action was commenced. ${ }^{4}$ Protection appears to have been extended to the basic dramatic situation or core of the play. ${ }^{5}$

At the same time, on rehearing of the Stanley case, involving submission of a radio program format, "Walter Wanger Presents," the court dealt with the theory of breach of implied contract to pay reasonable value. ${ }^{6}$ The plaintiff had included a count based on wrongful appropriation or infringement of copyright, but he was nonsuited on it and did not contend that this was error. The majority opinion is hard to analyze. Nominally the opinion

1 Golding v. R.K.O. Pictures, Inc., 208 P.2d 1 (1949); on rehearing, 35 Cal.2d 690, 221 P.2d 95 (1950); Stanley v. Columbia Broadcasting System, 208 P.2d 9 (1949); on rehearing, 35 Cal.2d 653, 221 P.2d 73 (1950). The opinions of the District Court of Appeal in the respective cases are at 193 P.2d 153 (1948), and 192 P.2d 495 (1948).

2 Weitzenkorn v. Lesser, 40 Cal.2d 778, 256 P.2d 947 (1953); Kurlan v. Columbia Broadcasting System, 40 Cal.2d 799, 256 P.2d 962 (1953). The opinions of the District Court of Appeal in the respective cases are at 231 P.2d 889 (1951), and 233 P.2d 936 (1951). Burtis v. Universal Pictures Co., 40 Cal.2d 823, 256 P.2d 933 (1953), will also be found interesting.

317 U.S.C. \& 2 (1947).

4 Prior to its amendment in 1947, CAc. Crv. CODE $\S 980$ read as follows: "The author of any product of the mind, whether it is an invention, or a composition in letters or art, or a design, with or without delineation, or other graphical representation, has an exclusive ownership therein, and in the representation or expression thereof, which continues so long as the product and the representations or expressions thereof made by him remain in his possession." See note 10 infra.

${ }^{5}$ In the Golding case the Supreme Court affirmed a judgment entered upon a jury verdict for the plaintifis for $\$ 25,000$.

${ }^{6}$ In the Stanley case the Supreme Court affirmed a judgment entered upon a jury verdict for the plaintiff for $\$ 35,000$. 
laid down restrictions on contract recoveries in line with the language of many cases in other jurisdictions. Justice Carter said: ${ }^{7}$

As a general observation from the cases, it may be stated that the right of the originator of an idea to recover from one who uses or mfringes it seems to depend upon whether or not the idea was novel and reduced to concrete form prior to its appropriation by the defendant, and, where the idea was disclosed by the originator to the appropriator, whether such disclosure took place under circumstances indicating that compensation was expected if the idea was used.

Where these prerequisites exist, recovery may be had upon a theory of contract implied in fact or in law....

Note the requirements of novelty and concreteness for a contract recovery, requirements also mentioned by Justice Schauer in his concurring opinion. But it was not clear that the majority was making any sharp distinction between wrongful appropriation or infringement of copyright and breach of contract, nor that it apprehended that there was any important difference in this class of cases between contract implied-in-fact and contract impliedin-law. One might emerge from a reading of the Golding and Stanley cases with the strange conclusion that plaintiff's idea needed less delineation for a recovery on a copyright basis than on a contract basis.

Justice Traynor dissented in both cases, ${ }^{8}$ laying down different lines of analysis with characteristic clarity and force. A majority of the court now appears to have come over to his way of thinking.

In the Weitzenkorn case ${ }^{9}$ where a somewhat less than idyllic story of "Tarzan in the Land of Eternal Youth" was at bar, California returns to the Union in limiting copyright protection to the "expression" of a work as distinguished froln its "idea" or "theme," at least as regards actions commenced after amendment of the provisions of the Civil Code; ${ }^{10}$ basic dra-

7 Stanley v. Columbia Broadcasting System, 35 Cal.2d 653, 656-7, 221 P.2d 73, 75 (1950).

8 On the Golding rehearing, Edmonds, J. wrote for himself and Gibson, C. J., Shenk and Carter, JJ.; Traynor, J. dissented with opinion in wbich Spence, J. concurred; Schauer, J. dissented with separate opinion. On the Stanley rehearing, Carter, J. wrote for himself and Gibson, C. J., Shenk and Edmonds, JJ.; Sehauer, J. concurred in separate opinion; Traynor, J. dissented with opinion in which Spence, J. concurred.

9 In the Weitzenkorn case, commenced after amendment of CaI. Crv. CoDE $\$ 980$, the complaint was in three counts: on express contract, on implied contract, and for wrongful appropriation. On appeal from a judgment sustaining demurrers to all counts, the Supreme Court upheld the first count, upheld the second count so far as it could be read as a count on contract imphed-in-fact, and dismissed the third count. Edmonds, J. wrote for himself and Gibson, C. J. and Shenk, J.; Traynor and Spence, JJ. concurred in the judgment; Schauer, J. concurred with short opinion; Carter, J. dissented with opinion.

10 After the 1947 amendment, § 980 read as follows: "The author or proprietor of any composition in letters or art has an exclusive ownership in the representation or expression thereof as against all persons except one who origimally and independently creates the same or a similar composition." For discussion of this and other statutory changes, see Edmonds, $\mathrm{J}$. in Weitzenkorn v. Lesser, 40 Cal.2d 778, 788-9, 256 P.2d 947, 955-6 (1953); cf. Traynor, J. dissenting in part in Kurlan v. Columbia Broadctsing System, 40 Cal.2d 799, 813-5, 256 P.2d 962, 972-3 (1953) ; Note, 38 CALx. L. REv. 332, 336-7 (1950); Fendler, The Present Status of Common Law Intellectual Property in California, 13 FED. Cosas. B. J. 114, 115-7 (1953). 
matic situation or core will not in itself be protected against infringement. Presumably conventional copyright standards will be applied throughout, so that originality, i.e., lack of copying by the plaintiff, not novelty, will be required as a condition of recovery on this theory..$^{11}$

In the same case, and again in the Kurlan case ${ }^{12}$ involving a radio script and program format of "My Sister Eileen," the court addresses itself to contract theory in contrast to copyright infringement. The court says that contract implied-in-law stands on much the same footing as copyright infringement and is no broader than the latter. ${ }^{13}$ Express contract and contract implied-in-fact are taken substantially as one, since both require manifestations of assent, although in differing forms. The approach is to consult the parties' probable intent; what were the parties bargaining for? The court suggests that if the implications of such a deal are made out in the proof, recovery can be had for the use even of an "abstract" idea, without "novelty," for the parties can bargain for a commonplace idea without detail if they are so minded. The contrasting approaches to copyright, on the one hand, and true contract, on the other, has been explained by Justice Traynor in part on the ground that copyright protection creates a kind of monopoly, and is therefore to be closely confined, while contract operates only between the parties. ${ }^{14}$

If the cases stopped at this point it might be said that a fairly broad reach was being given to the plaintiff. Under Golding and Stanley copyright had been loosened and contract nominally tightened; under Weitzenkorn and Kurlan copyright had been tightened and contract loosened. The whole development might have been said to furnish an illustration of the conception of some cynics that the law consists of paired or matched parables between which there is almost a free judicial choice.

But the court goes on to talk about the question of the inferences which may properly be drawn from the dealings of the parties. Justice Edmonds in the Weitzenkorn case says that it is "conceivable" that a writer may be

11 See the statutory language, note 10 sippra.

12 In the Kurlan case, commenced prior to amendment of CaL. Crv. CoDE $\$ 980$, the complaint was in five counts, on theories of express contract, contract implied-in-fact and impliedin-law, and wrongful appropriation. On appeal from a judgment sustaining demurrers to all counts, the Supreme Court reversed, upholding all counts. Edmonds, J. wrote for liimself and Gibson, C. J. and Shenk, J.; Schauer, J. concurred with short opinion; Traynor, J., in an opinion in which Spence, J. concurred, dissented in part, stating that he would uphold only the counts on express contract and contract implied-in-fact; Carter, $J$. dissented with opimion.

13 ". . . the proof necessary to recover upon the theory of a contract implied in law is the same as that required by the tort action for plagiarism." Edınonds, $J$. in Weitzenkorn v. Lesser, 40 Cal.2d 778, 795, 256 P.2d 947, 959 (1953). See also Traynor, J. dissenting in Stanley v. Columbia Broadcasting System, 35 Cal.2d 653, 675-6, 221 P.2d 73, 86 (1950).

14 Traynor, J. dissenting in the Stanley case Id. at 674, $221 \mathrm{P.2d}$ at $85 . \mathrm{My}$ friend John Schulman disputes the use of the word monopoly as applied to copyright. See generally Umbreit, A Consideration of Copyright, 87 U. OF PA. L. REv. 932 (1939). 
able to show that the parties entered into a contract for payment regardless of the "protectibility" of the writer's composition and no matter how "slight or commonplace" the portion used by the producer; but he adds that such an inference is "improbable." 15 This sounds like an allusion to what Justice Traynor said dissenting in the Stanley case: ${ }^{20}$

... It is not a reasonable assumption, however, in the absence of an express promise, or unequivocal conduct from which one can be implied, that one would obligate himself to pay for an idea that he would otherwise be free to use .... If the idea is not novel, the evidence must establish that the promisor agreed expressly or impliedly to pay for the idea whether or not it was novel....

Thus to an extent which is hard to measure-and especially so because the later cases arose only on the pleadings-barriers are raised against contract recoveries.

I shall now comment on the several strands of theory in the later opinions just summarized.

$\pi$.

The limitation of copyright protection to the "expression" of the work, as distinguished from its "idea" or theme, which on its face makes resort to copyright unavailing in many cases of this sort, will be received by most copyright specialists with the satisfaction of an old-time musician returning to Beethoven after a bout with Schoenberg. I feel myself sharing the sense of relief. California seems to have reverted, so far as its copyright law in this class of cases is concerned, to the standard of protectibility worked out under the federal statute, and in rescuing itself from unorthodoxy has also saved itself from a certain amount of confusion.

But, on reflection, how firm is the distinction between "expression" and "idea"? Let us first admit, as Mr. Kenneth B. Umbreit has observed, ${ }^{17}$ that copyright deals essentially with ideas in the ordinary meaning of the term: to copy the so-called expression of an idea is still to copy an idea. A workable distinction between ideas and expression miglit have been maintained when, as was originally the case, infringement of copyright meant essentially tracking a particular word order. We have come a long way since. When it was held that imitation of a sequence of events or incidents, as in plays, could constitute an infringement without any imitation of dialogue, ${ }^{18}$ and when it was intimated that a "character" sufficiently delineated might be infringed as a matter of copyright law without imitation of events or

1540 Cal.2d 778, 792, 256 P.2d 947, 958 (1953).

- 1635 Cal.2d 653, 674-5, 221 P.2d 73, 85-6 (1950).

17 Umbreit, supra note 14, at 950-1.

18 Sheldon v. Metro-Goldwyn Pictures Corp., 81 F.2d 49, 55 (2d Cir. 1936). 
incidents, ${ }^{19}$ it was idle to imagine that the idea-expression cleavage was a clear one, and by the same token the whole matter of infringement was put at large, as Learned Hand perceived. ${ }^{20}$ The distinction is especially hard to apply where two different media are involved, for example, when it is claimed that a motion picture infringes a novel. The fact seems to be that with the multiplication of economically valuable forms of intellectual production, standards of infringement or protectibility have become increasingly vague, and the end is not in sight.

The current California dispensation on copyright is therefore more ainbiguous than might be first supposed. Only a general guidepost has been set up, and that on shifting sands of doctrine. I am tempted to ask whether, in line with its acceptance of the idea-expression cleavage, a majority of the court is now prepared to say the following: that a radio format or plan, without specific incidents or specific delineation of character, and describing only the basic formula on which scripts are to be patterned, is beyond copyright protection except for the tracking of its words?21 Although Kurlan's radio format case was an action commenced prior to the amendments of the Civil Code, and is not therefore a fair test of the court's future action, I invite you to compare the majority's opinion with Justice Traynor's partial dissent.

\section{III.}

Turning to the contract implied-in-law, the coalescence of this theory with that of wrongful appropriation or copyright infringement seems to mean two interrelated things: (1) the court is emphasizing its refusal in this class of cases to recognize a standard of copyright protectibility lower than that which prevails generally in the copyright law; (2) the court prefers to handle any elements of claimed agreement between the parties under the more aptly descriptive headings, as it sees them, of express contract or contract implied-in-fact. The court appears to have followed the line of reasoning that once the consensual elements are shorn away from these cases, there is no ground of policy for setting up double and different standards for determining whether any liability exists-one standard for copyright, another for contract implied-in-law, neaning here no contract at all.

One may cavil at the statement in the Stanley dissent that there can be no recovery on contract implied-in-law unless "property" is being taken and used by the defendant, and if a work is not protected by copyright it is

${ }^{19}$ See Nichols v. Universal Pictures Co., 45 F.2d 119, 121 (2d Cir. 1930); cf. Burtis v. Universal Pictures Co., 40 Cal.2d 823, 835, 256 P.2d 933, 941 (1953).

20 Loc. cit. supra note 19.

21 Compare Fahy, C. J.'s remarks about a radio format or plan in Hamilton Nat. Bank v. Belt, 99 U.S.P.Q. 388, 390 (D.C. Cir. 1953). 
not "property."22 If property is only the sum of what the law protects by any means, this kind of argument is question-begging. There is nothing to prevent a court from defining literary property for the purpose of contract implied-in-law more broadly than it is defined for copyright infringement purposes. ${ }^{23}$ The question is only whether this would be wise, and the court has answered that question in the negative. The court's approach has the virtue of bringing out into the open any attempts to lower the standard of copyright protectibility. Such attempts can no longer unasquerade easily in the loose garb of quasi-contract. I should add that the coalescence of copyright infringement with contract inplied-in-law in the present class of cases does not necessarily mean that contract inplied-in-law will be denied separate status in the field of business ideas or schemes where there is, so to speak, less literary flavor, where the adjacent field of law may be patent rather than copyright.

Although contract implied-in-law now loses separate status as a rule for determining whether any liability exists in our class of cases, the Stanley dissent suggests that a plaintiff may still liave to elect between that theory and the theory of copyright infringement so far as measure of damages is concerned: for quasi-contract, according to the dissent, looks to the value of defendant's use, while copyriglit looks to the value of the thing taken. ${ }^{24}$ A requirement of "election" may be unfortunate, as it often is; what is primarily wanted is a sound method of computing the plaintiff's judgment whicl avoids any "double" recovery. Ordinary measures of recovery under the federal copyriglit statute furnish a guide, although the position there is not yet altogether clear. ${ }^{25}$

IV.

We now pass to the field of contract proper. The court lumps express with implied-in-fact contract for purposes of analysis, for no sharp distinctions can be made between words and other sigus in working out the meaning of a course of dealings. ${ }^{26}$ The troublesome cases will be those where the agreement is not explicit. And I remind you that the subject natter of the

2935 Cal.2d 653, 675-6, 221 P.2d 73, 86 (1950). This thought is repeated by Edmonds, J. in Weitzenkorn v. Lesser, 40 Cal.2d 778, 795, 256 P.2d 947, 959 (1953).

${ }^{23}$ It is not clear that the cases cited in the Stanley dissent to support an identical definition of "property" for both purposes really establish the point. See cases cited, Stanley v. Columbia Broadcasting System, 35 Cal.2d 653, 675, 221 P.2d 73, 86 (1950).

24 Id. at 676, 221 P.2d at 86.

25 Note the differing assumptions upon which the majority and minority opinions seem to go in F. W. Woolworth Co. v. Contemporary Arts, Inc., 344 U.S. 228 (1952).

${ }^{26}$ But as the signs tend toward the lacomic, the court's role becomes creative rather than merely interpretative, and there is greater room and reason for the court to give judgment according to its own ideas of fairness. Cf. Kessler, Contracts of Adhesion, 43 Cor. L. REv. 629, 637 (1943). 
agreement, if there is one, will be an "idea," or rather something that will not pass muster in California as protectible "expression."

As I have intimated, it is a contribution to clarity to consider any elements of agreement under contract express or implied-in-fact, rather than implied-in-law; this use of terms will in itself help to concentrate attention upon and force conscious appraisal of the circumstances of the submission and the conduct of the parties.

Now there seem to me to be three main points. (1) Having broken away from any freewheeling and undiscriminating use of contract miplied-inlaw, how meticulous will the court be in insisting on standard elements of contract formation when it decides whether a contract exists? (2) How far will the intent of the parties actually be pursued when it clashes with such notions as "novelty"? (3) What precisely do "novelty" and related concepts mean?

Professor Patterson of Columbia, in an excellent study in 1952 for the New York Law Revision Commission, ${ }^{27}$ subjects certain "business idea" cases to analysis along ordinary contract lines. He shows, on varying states of the evidence, how delicate are the factors making for and against a finding of offer, acceptance and present consideration. What expectation on the part of the writer is shown by the act of submission? What understanding is evinced by the producer when he considers the writer's work or uses all or a part of it? What is the bearing of the fact that the work may be submitted and disclosed to the producer against his expressed wishes?

It is not feasible to deal here in detail with these and other questions of interpretation that will readily come to mind. I want, instead, to make a general point which will be sufficiently suggested by the case where an idea is submitted, examined, returned to the writer as rejected, and then used to some extent by the producer. Would recovery on these facts be properly classified as based on contract implied-in-fact or contract implied-by-law? As the facts shade off, classification becoines more difficult. The line is hard to draw, ${ }^{28}$ yet the court has made a great deal turn on it. In the degree that the hine is doubtful the California Supreme Court has a wide range of choice in these cases and could revive ambiguities which it has heroically striven to exclude.

Next, although the court now makes the parties' probable intent the lodestar of decision, terms such as "novelty" appear in the significant remarks of Justices Edmonds and Traynor ${ }^{29}$ on the implications and inferences to be drawn froin the facts.

2r Compensation for Unsolicited Disclosure of Business Ideas, N. Y. Legis. Doc. (1952), No. $65(\mathrm{R})$.

${ }^{28}$ See Frank, C. J. in Martin v. Campanaro, 156 F.2d 127 (2d Cir. 1946).

29 Notes 15 and 16 supra. 
Some background is needed. Cases decided elsewhere over the past few decades, dealing for the most part with business or advertising ideas, made much of "novelty" and "concreteness" as prerequisites to contract recovery. It is an echo from these cases that was heard in the majority opinion in the Stanley case ${ }^{30}$ and before that in the $Y a d k o e$ case $^{31}$ in a lower California court.

In particular cases these requirements could be justified as really conforming to the parties' intent; for example, at the time of submission the claimant himself might well be willing to have his compensation depend on whether he really has something new and in readily usable form. But in other cases one has the impression that novelty and related requirements were imposed without any nice regard to intent but for other reasons: they were convenient handles for disposing of hard questions such as similarity and use, and they served a generally restrictive purpose in the hands of courts that felt a lively skepticism about "hot idea" claims.

Let us see what part novelty plays in the theoretical structure created by the latest California cases. It is now intimated that a commonplace idea may be compensable if that was the bargaim; but unless the proof to the contrary is clear-and when is it likely to be clear?-the court will surmise that payment was intended only if the idea was novel. A notion of novelty is thus introduced in terms of the parties' probable intent; but if it becomes a rather rigid requirement as in the past, will it not sometimes be antagonistic to the search for intent? Are producers looking for novelty or just for something that will catch on, whether or not it is novel?

In the Stanley dissent there is a suggestion of a further factor, commercial value. We are indeed warned not to infer too quickly that a novel feature is cominercially valuable, for it may be that what makes a program popular and therefore valuable is its familiar rather than its novel features. ${ }^{32}$

Now what exactly is novelty? The court has not attempted a definition but in the Stanley dissent novelty appeared to be some species of imaginative invention or discovery beyond mere originality as in the law of copyright; thus it became necessary to examine earlier radio shows to find whether there was precedent for the program format or the particular feature of it in suit. How far back must the search be carried? Does the plaintiff's or defendant's ignorance of the precedents make any difference? Suppose an idea is old, perhaps well-known and even lying dormant in the producer's files, but brought to his mind only through the submission? Is it

${ }^{30}$ See the quotation in the text following note 7 supra.

31 Yadkoe v. Fields, 66 Cal. App.2d 150, 151 P.2d 906 (1944).

32 See Stanley v. Columbia Broadcasting System, 35 Cal.2d 653, 681-2, 221 P.2d 73, 90 (1950). 
not evident that answers to questions such as these may turn on whether it is probable intent we are really pursuing?

Justice Traynor did not mention concreteness in the relevant portion of the Stanley dissent, and this is quite natural, simce he was seeking to distinguish an appropriation or copyright cause of action, where in his view plaintiff must show imitation of "expression," from a contract cause where defendant inay be charged even for a mere abstract idea. Justice Edmonds in the Weitzenkorn case does not stress concreteness in relation to a contract recovery, but as we have seen he does mention the "protectibility" of the work as a factor in establishing such a recovery. How far does this project into the contract cause of action something akin to the standard of protectibility laid down by the court for copyright infringement? Are we back, then, to some notion of concreteness, also introduced as part of the search for intent?

One may question how far novelty and related factors are necessarily a guide to probable intent where the bargain is inchoate; but this is not to say that these factors will be without meaning or value for that purpose in cvery case. Further, a court might rationally impose such requirements without regard to intent or ordinary primciples of contract law, simply as means of brimging order into a refractory field and easing the administrative problem of dealing with amorphous facts. At this stage the Califorma cases still leave room for choice of objectives and clearer defimitions. Again it is worth recallimg that both the Weitzenkorn and Kurlan cases arose on the pleadings (as amplified by the texts of the compositions in suit) where fine points of theory could be overlooked.

Finally the question of similarity arises. If the alleged implied contract is to pay for plaintiff's material if used, and use means inclusion in defendant's production, comparison becomes necessary. The court has disclaimed applying copyright standards in the contract field and is presumably remitted to applying even vaguer standards. As a means of gaining a toehold for climbing this straight wall the court may consciously or subconsciously look to concreteness; so that, even if thrown out the front door, this concept may come in the back door, possibly unannounced. So also it may have its place, along with novelty, in assessing damages.

To sum up on the whole substantive position in California: The Supreme Court has created a structure the effect of which is to expose the critical questions in the cases. This is all to the good. There are difficulties in the distinctions taken and in the terms used, but to some extent these are unavoidable on any view except the most Draconian.

v.

I pass over the more technical questions of pleading a count in imphed contract. 
The court in the Kurlan case allowed a count based on custom to stand as a pleading. As an outsider I should doubt whether unambiguous custom will often be provable, notwithstanding some reliance on custom in the Stanley case; and there is the remaining question whether the parties in a given situation are dealing by reference to custom, if there is one.

I would say also that while pleaders have adopted a pattern of alleging a contract to pay reasonable value for plaintiff's material if used, on variant facts it might be plausible to allege a contract to pay reasonable value for plaintiff's services if his material was used, or even if it was experimented with and not used. And there are other possibilities. Such pleadings would still further test the court's willinguess to pursue the parties' intent wherever it might lead.

VI.

In a relatively fluid condition of the law, counselors to writers and producers strive to attain greater certainty by shaping the facts in advance of contest. The literature contains multitudinous suggestions about how companies can avoid liability by devising suitable routines in handling material submitted from the outside, and by contract forms and releases; it has sonsething, also, on how idea originators can improve their positions in case of later dispute. I would say, first, that in the drafting of contract and release forms companies ought to remember what has happened to supposedly ironclad releases in accident cases. The books are strewn with successful attacks on releases-attacks which were successful essentially because the releases looked unfair. The second point is that while systems can be set up to avoid involvement with casual amateurs who submit material, it may be doubted whether it is practicable to deal at stiff arm's length with professionals. Thus claims will continue to be asserted in the "hot idea" business which seems to be getting ever warmer.

An outsider is struck by the contradictory assertions that have been made over the years that tight rules himiting recovery would be (1) hurtful to writers because producers would use the rules to wrest valuable ideas from writers without paying for them; (2) helpful to writers because in the absence of such rules producers would simply refuse to deal with writers. One wonders whether there is any way in the world to test these hypotheses with anything approaching accuracy.

My last duty is to tell you whether there is a trend for one side or the other in these cases; for I find that no discussion is considered complete without an assessment of trends. But I am chastened by a piece that I recently read. The author showed that the trend was for the plaintiff and he quite reasonably used the Califorma cases of Golding and Stanley to make his ponit. That was before the Weitzenkorn and Kurlan cases were decided by the Suprenie Court. 
In the face of this example, I will trend no trends; and thus I conclude my explication of text..$^{33}$

${ }^{33}$ For cases arising in California under the regime of the Weitzenkorn and Kurlan cases, see Sutton v. Walt Disney Prod., 118 A.C.A. 699, 258 P.2d 519 (1953), Palmer v. MetroGoldwyn-Mayer Pic., 119 A.C.A. 524, 259 P.2d 740 (1953), and Taylor v. Metro-GoldwynMayer Studios, 115 F. Supp 156 (S.D. Cal. 1953) ; the results on varying facts were all unfavorable to the plaintiffs. [With the remarks on "trade secret" in the Taylor case, compare Restatement, Torts $\$ 757$ (1939).] The Court of Appeals, District of Columbia Circuit, in affirming a judgment for the plaintiff in a radio format case, Belt v. Hamilton Nat. Bank, 108 F. Supp. 689 (D.D.C. 1952), aff'd, 99 U.S.P.Q. 388 (D.C. Cir. 1953), does not speak in the same terms as the recent California cases. It makes a good exercise to attempt to apply the canons of the Weitzenkorn and Kurlon cases to the facts of the Belt case; one acquires a lively conviction of the range of choice still available to the California Supreme Court. 